\title{
RELEVANSI FATWA MAZHAB SYAFI'I TENTANG KUFU DALAM NIKAH TERHADAP KOMPILASI HUKUM ISLAM (KHI)
}

\author{
Hasan Bashori \\ Alumni FAI UCY \\ Cipto Sembodo \\ FAI UCY
}

\begin{abstract}
This article aims to examine the fatwa of kufu from the famous Shafi'i school and its relevance to the marriage regulations in Indonesia, specifically the Compilation of Islamic Law (KHI). This library research also uses fatwa comparisons between schools and comparison between laws and regulations to obtain data. In Islamic law, it is not permissible to prevent marriage just because of different kufu. The kufu law is excluded in terms of religion because it can bring household into disharmony. This, in the end, turned out to be recognized both in the fatwa of Shafi'i schools and KHI.
\end{abstract}

Keywords: Kufu, Shafi'i School, Compilation of Islamic Law

\begin{abstract}
Abstrak: Tulisan ini bermaksud menelaah fatwa kufu dari mazhab Syafi'i masyhur dan relevansinya dengan peraturan perkawinan di indonensia, khususnya Kompilasi Hukum Islam (KHI). Penelitian pustaka iki ini juga mneggunakan perbandingan fatwa anata mazahab mapun hokum perundang-undangan untuk mendapatkan data. Karena itu, dalam hukum Islam, tidak dibolehkan mencegah perkawinan hanya gara-gara berbeda kufu. Hokum itu dikecualikan dalam hal agama karena itu bisa mengganggu dalam keharmonisan dalam rumah tangga. Hal yang samasama diakui dalam fatwa mazhab Syafi'i dan KHI.
\end{abstract}

Kata Kunci: Kufu, Mazhab Syafi‘i, Kompilasi Hukum Islam

\section{A. Pendahuluan}

Perkawinan merupakan perjanjian yang unik di banding yang lain. Dalam Bab I Pasal I Undang-Undang Nomor 1 Tahun 1974 tentang Perkawinan dijelaskan bahwa yang dimaksudkan dengan perkawinan adalah ikatan lahir batin antara seorang pria dengan seorang wanita sebagai suami isteri dengan tujuan untuk membentuk keluarga sejahtera, kekal berdasarkan Ketuhanan Yang Maha Esa. Di sini jelas bahwa hukum perkawinan di Indonesia menghendaki suatu perkawinan yang bertujuan membentuk keluarga sejahtera, kekal berdasarkan Ketuhanan Yang Maha Esa. 
Karena keunikannya itu, dalam proses penentuan pasangan suami istri untuk berhati-hati dan mempertimbangkan banyak hal. Sangat dianjurkan untuk memilih yang sefaham, seimbang, setingkat dan sederajat. Meskipun ini bukan suatu keharusan, tetapi ini dimaksudkan agar menghasilkan kesearasian dalam rangka menghindarkan cela. Karena seringkali kegagalan dalam membina sebuah rumah tangga disebabkan oleh perbedaan-perbedaan yang mencolok, baik perbedaan dalam agama maupun dalam strata sosial. Perbedaan-perbedaan tersebut dapat menjadi sumber perselisihan yang pada akhirnya menyebabkan ketidakharmonisan keluarga. Pendapat senada juga diungkapkan oleh para psikolog yang menganjurkan, agar antara dua pasangan jangan sampai ada perbedaan yang jauh, apalagi bertentangan antara satu dengan lainnya, baik dalam tingkatan pemahaman, sosial dan kepribadiannya. ${ }^{1}$

Nur Dalam rangka mencari pasangan hidup untuk membentuk suatu keluarga, orang tua atau pihak yang bersangkutan pada umumnya memperhatikan pasangannya terlebih dahulu. Dan dalam memilih pasangan diharapkan adalah orang yang sekufu.Sedangkan maksud sekufu dalam perkawinan adalah keseimbangan atau keserasian antara (calon)suami istri sehingga masing-masing (calon) tidak merasa berat untuk melaksanakan perkawinan. ${ }^{2}$

Persoalan sekufu menjadi penting. Karena tujuan perkawinan itu ialah mendapatkan ketenangan, keamanan, kasih sayang dan belah kasihan. Apabila calon suami maupun istri memilih pasangan yang dia benci, sudah tentu kehidupannya tidak tentram dan kemungkinan akan berlaku pergeseran serta perceraian, jadi hakikat sekufu ini mempunyai peranan yang sangat besar dalam hubungan suami maupun istri. 3

Dalam Fikih Mazhab, Fatwa kufu dari Mazahab Syafi'i telah memiliki kekhasan. Secara keseluruhan, mazhab ini telah menjadi panutan umat Islam di Indonesia. Tulisan ini bermaksud menelaah kufu

${ }^{1}$ Subhan Nurdin, Kado Pernikahan Buat Generasiku (Bandung: Mujahid Press, 2002), h. 93

2 Djam'an Nur, Fiqih Munakahat (Semarang:Penerbit Dina Utama, 1993), 76

3 Soemiati, Hukum Perkawinan Islam dan Undang-Undang Perkawinan; Undang-Undang No.1 Tahun 1974 tentang Perkawinan (Yogyakarta:Liberty,1982), h. 85 
dari mazhab masyhur ini kemudian dijelaskan relevansinya dengan peraturan perkawinan di indonensia, khususnya Kompilasi Hukum Islam (KHI)

\section{B. Pengertian Kufu}

Kata kufu berasal dari kufu dalam bahasa Arab, كفئ- ككفئ- كفائة. Dalam al-Munawwir bermakna setara atau sederajat.4 Ghozaly juga mengartikan sama. Definisi etimologisnya berarti al-Musawah dan al-Mumasalah yaitu sama, sebanding, atau setaraf. 5

Istilah kemudian dikhususkan dalam fikih nikah. Dalam perkembangannya, Zainuddin al-Malibari menyimpulkan dalam kitab Fathu al-Mu'in berkata bahwa kufu dibahas dalam masalah pernikahan ketika membicarakan perjodohan seorang wanita. Dalam fikih mazhab ada kesepakatan, kufu merupakan hak seorang wanita dan walinya, dan keduanya boleh menggugurkannya. 6

Dari situ, Dahlan menyimpulkannya berupa kesetaraan yang perlu dimiliki oleh calon suami dan istri agar dihasilkan keserasian hubungan suami-istri yang mantap dalam rangka menghindari cela dalam permasalahan-permasalahan tertentu. ${ }^{7}$ Bagi Supriyadi, keseimbangan dan keserasian antara calon suami dan calon istri itu bermakna masing-masing calon tidak merasa berat untuk melangsungkan pernikahan. ${ }^{8}$ Ghozaly membatasi pada keseimbangan, keharmonisan dan keserasian, terutama dalam hal agama, yaitu akhlak dan ibadah. Ia tidak mengakui persamaan dalam hal harta, atau kebangsawaan. Bila disyaratkan, maka akan terbentuk kasta. Sedang dalam Islam hal itu tidak dibenarkan, karena manusia di sisi Allah adalah sama, hanya takwa yang membedakan. 9

Salah satu contoh pasti ada dalam al-Quran berupa kesederajatan

4 Achmad Warson Munawwir dan Muhammad Fairuz, Kamus al-Munawwir Indonesia-Arab (Surabaya: Pustaka Progresif, 2007), h. 375

5 Abdul Rahman Ghozaly, Fikih Munahakat (Bogor: Kencana, 2003), h. 96 tt), h. 106

${ }^{6}$ Zainuddin al-Malibari, Fathu al-Mu ìn (t.t.p: Dār al-Ihyā' al-Kutub al-'Arabiyah,

7 Abdul Aziz Dahlan dkk., Ensiklopedia Hukum Islam (Jakarta: PT. Ikhtiar Baru van Hoeve, 2001), II: 845

8 Dedi Supriyadi, Perbandingan Hukum Perkawinan Islam Di Dunia Islam (Bandung: Pustaka Al-Fikri, 2009), h. 60.

9 Ghozaly, Fikih Munahakat, h. 96 
dalam agama masing-masing calon pengantin. Dalam surat al-Baqarah [2]:221 telah jelas dinyatakan bahwa orang yang beriman tidak boleh menikahi wanita musyrik, begitu pula sebaliknya wanita-wanita mukmin tidak boleh dinikahkan dengan orang-orang musyrik. Mereka, orangorang mukmin dan wanita-wanita mukmin baru boleh menikah dan dinikahkan dengan wanita-wanita musyrik dan orang-orang musyrik kecuali kapan wanita-wanita musyrik dan orang-orang musyrik itu telah beriman.

Bagi mzahab Hanafi, kufu dalam nikah adalah kesetaraan dan kesesuaian antara calaon mempelai lelaki dan perempuan dalam perkaraperkara tertentu.

Kesesuaian diartikan oleh tokoh mazhab fikih, pengarang kitab alUmm, Syafi'i, dengan tetap menuruti keumuman pendapat jumhur ulama yang tetap merujuk kepada asal katanya. Kesederajatan dan keseimbangan yang tidak kurang antara lelaki dan perempuan dalam nikah. Pendiri salah satu mazhab masyhur itu menegaskannya sebagai bagian persyaratan keabsahan nikah. Seorang ayah tidak bisa menikahkan anak gadisnya dengan pria yang tidak sekufu. "Yang tidak mengindahkan berarti telah meninggalkan kekurangan bagi calon mempelai perempuan."10 Karenanya salah satu pengikutnya, Bakri dalam Abu Bakar, kemudian mendefinisikan kufu sebagai perkara yang ketiadaannya menjadikan kehinanaan. ${ }^{11}$ Pengertian itu kemudian diserap oleh ulama kontemporer, Zuhaili, yang membatasinya sesuai dengan pengapat pendahulunya. kesepadanan antara kedua pasangan sebagai bentuk pencegahan kecacatan dari beberapa aspek. ${ }^{12}$

\section{Hokum Kufu}

Kekhawatiran akan munculnya keretakan dalam rumah tangga inilah yang menyebabkan mengapa syarat adanya kufu di dalam pernikahan sehingga seorang wanita tidak boleh menikah dengan laki-laki

10 Imam Abī Abdillāh Muhammad ibn Idris ash-Shāfi'i, al-Umm (Beirut: Dār alIhyā' al-Turāṭ al- 'Arabi, 2001), h. 77

11 Abu Bakar, "Kafaah Sebagai Pertimbangan Dalam Perkawinan Menurut Mazhab Syafi'i," Jurnal Hukum Kaidah, Voume :18, Nomor : 1, p. 52-65

12 Ibid. 
yang tidak sederajat dengannya. ${ }^{13}$ Syafi'i tidak memperbolehkan seorang wanita dinikahkan dengan laki-laki yang tidak sekufu' karena akan muncul sebuah kekurangan pada diri wanita tersebut. Kekurangan itulah yang mungkin nantinya di suatu hari, yang apabila pernikahan tersebut tetap dilangsungkan, akan menimbulkan keretakan dalam rumah tangga. Ketidakbolehan tersebut sekaligus menyiratkan bahwa Imam Syafi’i mensyaratkan adanya unsur kufu dalam pernikahan yang menjamin seorang wanita hanya menikah dengan laki- laki yang sekufu untuk menghindari adanya kekurangan yang muncul pada diri wanita tersebut yang pada gilirannya mencegah timbulnya keretakan pada hubungan rumah tangga karena pernikahan antara seorang wanita dengan laki-laki yang tidak sekufu'.

Syafi'i memang tidak menentukan hokum secara ketat aturannya. hal itu terlihat dari pandangannya yang melarang seorang wanita dinikahkan dengan laki-laki yang tidak sekufu. Namun dalam bagian lain dari al-Umm, Imam Syafi’i menyatakan pernikahan antara seorang wanita dengan laki-laki yang tidak sekufu' itu tidak haram. ${ }^{14}$

Imam Syafi’i r.a. berpendapat bahwa kufu disyaratkan dalam ikatan pernikahan justru karena kufu tersebut boleh ditiadakan atau dibatalkan. Hal ini menjadi sangat masuk akal apabila kufu diatur sebagai hak dari pihak mempelai wanita beserta walinya.

Dalam pandangan fuqaha lain, pihak yang paling berhak menentukan adalah Allah. Hal itu tercemin denga ketaaatan terhadap hukum-hukumnya yang berhubungan dengan keserasian calon-calon mempelai. Hak Allah ini harus dipenuhi, karena menjadi syarat sahnya suatu pernikahan. Bila hak Allah tidak dipenuhi, maka pernikahan itu menjadi batal. Hak Allah dalam hal kafa'ah adalah: hendaknya pernikahan itu dilakukan oleh laki-laki dan wanita yang sama-sama Islam. Disamping itu, dipandang kufu' antara laki-laki muslim dengan wanita-wanita ahl alKitāb yang menjaga kehormatannya.

Aini kemudian menyebutkan pemilik hak, yaitu pihak-pihak yang

13 ash-Shāfi'i, al-Umm.

14 Ibid, h. 66 
berkepentingan dalam pernikahan. Orang yang berkepentingan dalam pernikahan itu adalah calon-calon mempelai laki-laki yang mukallaf dan wali mempelai perempuan. Calon-calon mempelai mukallaf adalah orang yang mempunyai hak pernikahannya. Hak itu lebih besar dari hak walinya. Sedangkan calon mempelai yang belum mukallaf. Hak kufu itu berada di tangan walinya. ${ }^{15}$

Bagi Syafi'I, calon mempelai wanita dan walinya tetap berhak memilih untuk mempertahankan syarat kufu ataukah membatalkannya dalam pernikahannya. Pilihan demikian hanya berlaku manakala seorang wanita akan dinikahkan dengan laki-laki yang tidak sekufu.

Apabila tetap mempertahankan unsur kufu, dengan sendirinya pernikahan tersebut tidak boleh dilangsungkan karena syarat kufu tidak terpenuhi anatara calon suami dan istri. Jika wali atau mempelai perempuan ingin melepaskan syarat itu, maka pernikahan boleh dilangsungkan dengan terlebih dahulu memenuhi persyaratan dalam pembatalan kufu.

Ia juga mengakui bahwasannya kufu itu disyaratkan dalam pernikahan dan tidak memperbolehkan wanita untuk dinikahkan dengan laki-laki yang tidak sekufu. Namun, apabila tetap bersikeras untuk dinikahkan, maka pernikahan tersebut boleh dilangsungkan dan tidak diharamkan dengan catatan adanya pembatalan kufu dengan terlebih dahulu memenuhi syarat-syaratnya. Meski berdampak kepada keberlangsungan pernikahan, tetapi kufu kemudian bukanlah syarat untuk itu. Status syaratnya hingga keabsahan akad pernikahan saja.

Ada dua kondisi yang harus terpenuhi untuk dapat membatalkan unsur kufu. Hal pertama yang harus terpenuhi adalah kerelaan diri dari si calon mempelai wanita itu sendiri. Wanita yang dipinang oleh laki- laki tentunya mengetahui bahwa derajatnya lebih tinggi dari si laki-laki. Calon mempelai wanita harus rela menerima bahwa apabila dia melangsungkan pernikahan dengan laki-laki yang bukan keturunan ningrat, maka derajatnya yang tinggi sebagai keturunan ningrat akan

${ }_{15}$ Abu Muhammad Mahmud bin Ahmad al-Aini, al-Bidāyah fi Sharh al-Hidāyah (Beirut: Dār al-Fikr, 1990), IV:231. 
turun. Turunnya derajat si wanita keturunan ningrat ini karena derajat wanita tersebut diikutkan pada derajat suaminya yang lebih rendah darinya.

Kerelaan diri calon mempelai wanita merupakan persetujuan atau izin dari si wanita tersebut untuk dinikahkan dengan laki-laki yang mempunyai derajat lebih rendah darinya. Imam Syafi'i berkata bahwa wali yang akan menikahkan gadis dalam perwaliannya haruslah mendapatkan izin dari gadis tersebut. Dia mau ataukah tidak apabila akan dinikahkan dengan laki-laki pilihan walinya. ${ }^{16}$

Dalil di atas memperlihatkan bahwa untuk menikahkan seorang gadis dengan laki-laki yang se-kufu', seorang wali haruslah mendapatkan izin dari si wanita dalam perwaliannya. Secara logika, apabila untuk menikahkan seorang wanita dengan laki-laki yang se-kufu' saja harus mendapatkan izin dari si wanita itu, berarti apabila akan dinikahkan dengan laki-laki yang tidak se-kufu' tentunya harus lebih mendapatkan izin dari si wanita calon mempelai.

Hal kedua yang harus terpenuhi adalah kesepakatan dan persetujuan semua wali dari wanita tersebut bahwa dia akan melangsungkan pernikahan dengan laki-laki . Sama halnya seperti calon mempelai wanita, semua wali dari wanita tersebut harus rela menerima derajat mereka akan turun apabila wanita dalam perwalian mereka melangsungkan pernikahan dengan laki-laki.

Semua wali harus bersepakat dan menyetujui pernikahan tersebut. Disebutkan semua wali karena bukan hanya wali yang berhak menikahkan melainkan semua wali dari calon mempelai wanita tersebut. Kesepakatan dari semua wali ini berpengaruh pada sah atau tidaknya pernikahan yang tidak sekufu'. Hal ini sesuai dengan perkataan Imam Syafi'i r.a. ${ }^{17}$

Kesepakatan dan persetujuan dari semua wali itu adalah bukti bahwa para wali dari pihak calon mempelai wanita bersedia untuk mengugurkan unsur kufu, tidak boleh ada satu pun wali dari pihak

${ }^{16}$ ash-Shāfi'i, al-Umm, h. 66

17 Ibid. 
mempelai wanita yang menyatakan keberatan atas pernikahan yang akan dilangsungkan. Apabila ada satu saja wali yang tidak menyetujui atas pernikahan tersebut, maka pernikahan antara kaum ningrat dengan kaum nonningrat tersebut dianggap tidak sah. ${ }^{18}$

Persetujuan semua wali harus dilakukan sebelum akad nikah berlangsung. apabila dilakukan sesudah dilangsungkannya, maka wali tersebut dianggap belum bersepakat sehingga berimbas pada pembatalan (fasakh) pernikahannya. ${ }^{19}$ Begitu juga apabila ada wali sebelum akad nikah telah setuju, kemudian berkeberatan sesudah akad berlangsung, maka tidak berpengaruh pada sah atau tidaknya pernikahan tersebut.

Hal ini karena akad nikah sudah dilakukan dan sebelumnya semua wali tersebut sudah bersepakat dan menyetujui untuk menyelenggarakan pernikahan antara kaum ningrat dengan kaum nonningrat dengan kerelaan dari diri calon mempelai wanita. ${ }^{20}$

Perkawinan yang tidak sekufu itu tidaklah diharamkan, dengan setiap keadaan dan sesungguhnya kekurangan kepada wanita yang dikawinkan dan kepada wali-wali, maka apabila disetujui bersama wanita itu dengan segala kekurangannya kekurangannya maka Syafi'i tidaklah menolaknya, apabila dikawinkan oleh seorang wali dengan yang sekufu dan ia mengurus urusan wanita tersebut. ${ }^{21}$

Imam Syafi'i berkata apabila telah bersepakat wali-wali untuk menjadi wali syara' bagi wanita tersebut, dan wali itu yang lebih utama atau lebih tua dan apabila dia patut untuk menjadi wali atas wanita tersebut, maka apabila disetujui oleh wali yang tidak terdekat untuk mengawinkan dengan laki-laki yang tidak sekufu. Namun perkawinannya ialah dengan izin wanita dan wali syara', apabila walinya tidak setuju maka perkawinannya batal. Dan upaya untuk mencari persamaan antara calon suami maupun istri yang baik dalam kesempurnaan hidup maupun keadaan. $^{22}$

18 Ibid

19 Ibid.

20 Ibid.

21 Ibid.

22 Jazairi, Al-Fiqh 'Alā Al-Mazāhib Al-Arba'ah (Beirut:Dār al-Fikr, 1969), h. 57 
Degan demikian, hokum kufu sebagai syarat bagi Imam Syafi'i fleksibel. Kelenturan itu dengan mempertimbangkan kepentingan calon perempuan untuk mencegah timbulnya hal- hal yang tidak diinginkan dalam pernikahan dengan mensyaratkan adanya unsur kufu, daripada mengambil resiko memperbolehkan melangsungkan pernikahan yang tidak se-kufu tanpa ada syarat kufu sama sekali. ${ }^{23}$

Dalam pandangan Iffatin Nur, pemikiran yang mengutamakan hak calon perempuan seperti mazhab Syafi’i itu berdampak pada kemaslahatan dan progresifitas muslimah. pertimbangan mempelai perempuan merupakan unsur pokok dalam mahligai pernikahan, Maka sudah seharusnya berperan utama dalam menetapkan usulan kriteria kufu. ${ }^{24}$

\section{Standar ukuran dalam Kufu}

Konsep kufu imam Syafi'i berbeda dengan konsep kufu imam-imam yang lainnya seperti imam Hanafi, Hambali dan Maliki dan imam yang lainnya, kalau imam Syafi'i konsep kufunya meliput : kebangsaan, keagamaan, kemerdekaan dan mata pencarian. Namun yang membedakan konsep kufu imam Syafi'i dan imam yang lainnya ialah dari segi kekayaan, imam Syafi'i memaknai kekayaan itu dengan mata pencarian bukan dengan banyaknya harta kekayaan dalam kehidupan sehari-hari, tapi imam Syafi'I memaknainya dengan mata pencarian atau pendapatan.

Namun para imam lainnya memaknai kekayaan dalam konsep kufu itu memaknainya dengan kesanggupan membayar mahar dan yang dimaksud dalam kesanggupan membayar mahar ialah sejumlah uang yang dapat dibayarkan dengan tunai mahar yang diminta, dan apabila tidak memiliki harta untuk membayar mahar dan nafkah atau salah satunya, maka dianggap tidak sekufu. Tapi menurut imam Syafi’i memaknai kekayaan itu dengan mata pencariannya sendiri yaitu pendapatannya dalam bekerja seharihari bukan dengan banyaknya harta dalam kehidupan. Menurut imam Syafi’i bahwa kekayaan itu tidak dapat

23 ash-Shāfi'i, al-Umm, h. 77

24 Iffatin Nur, "Pembaharuan Konsep Kesepadanan Kualitas (Kafaa'ah) Dalam Al-Qur'an Dan Hadis," Kalam: Jurnal Studi Agama dan Pemikiran Islam Volume 6, Nomor 2, Desember 2012, h. 411-436 
dijadikan ukuran kufu, karena kekayaan itu bersifat timbul tenggelam dan suatu saat akan musnah.25 dan imam Syafi’i memaknainya dengan mata pencarian yaitu dengan pendapatannya, dan menurut imam Syafi'i orang yang banyak harta belum tentu memiliki pendapatan dari hasilnya sendiri, boleh jadi kekayaannya dia dapatkan dari keturunannya memang kaya. Jadi banyaknya harta tidak bisa jaminan atau ukuran untuk kekufuan seseorang, maka dari itu imam Syafi'i memaknainya dengan mata pencarian atau pendapatannya dalam bekerja bukan dalam banyaknya harta kekayaan.

Konsep kufu dalam pernikahan yang diterapkan oleh imam Syafi'i adalah menyamakan kedudukan calon mempelai laki-laki dan calon perempuan. Hokum kufu bertujuan menjaga keseimbangan antara kedudukan status calon suami dan istri, kedudukan status suami tidaklah melebihkan kedudukan status istri, karena jika wanita lebih tinggi kedudukannya dari suami, maka dikhawatirkan akan menimbulkan aib bagi kehidupan rumah tangganya kelak.

Namun jika kedudukan suami lebih tinggi maka ulama Syafi'iyah tidak mempersoalkannya, karena tidak akan menimbulkan mudharat bahkan jarang sekali timbul masalah yang serius yang berkaitan dengan status, tapi apabila wanita dan walinya ridoi dengan laki-laki atau calon suaminya yang lebih rendah kedudukannya dari kedudukan wanita itu maka tidak ada masalah apabila wali rido, namun harus seizin walinya terlebih dahulu untuk melangsungkan pernikahan.

Fitrah manusia untuk memenuhi kebutuhan hidupnya baik secara lahiriyah maupun bathiniyah, maka hal ini mendorong manusia untuk senantiasa berupaya memperoleh segala sesuatu yang menjadi kebutuhannya, pemenuhan kebutuhan lahiriyah identik dengan terpenuhinya kebutuhan dasar berupa sandang, pangan dan papan, tapi manusia tidak berhenti sampai disana, bahkan cenderung terus berkembang kebutuhan-kebutuhan lain yang ingin dipenuhi. Segala kebutuhan itu seolah-olaah bisa diselesaikan dengan dikumpulkannya harta.

25 Sayyid Sabiq, Fiqih Sunnah (Bandung: al-Ma’arif, 1981,), VII:37 
Yang dimaksud harta ialah : harta atau Al-Mal dalam Al-Quran dan sunnah tidak dibatasi dalam ruang lingkup makna tertentu, kriteria harta menurut para ahli Fiqih terdiri dua bagian yaitu : pertama memiliki unsur nilai ekonomis dan yang kedua adalah unsur manfaat atau jasa yang diperoleh, nilai ekonomis dan manfaat yang menjadi kriteria harta ditentukan berdasarkan kebiasaan yang berlaku dalam masyarakat. Dengan demikian tempat bergantung status Al-Mal terletak pada nilai ekonomis, besar atau kecilnya dalam harta tergantung besar dan kecilnya manfa'at. Faktor manfaat menjadi patokan dalam menetapkan nilai ekonomis , maka manfaat suatu barang menjadi tujuan dari semua jenis harta.

Mata pencarian adalah: pekerjaan, pekerjaan merupakan hal yang sangat penting bagi manusia. Tanpa profesi bermata pencaharaian, ia akan mengalami kesulitan hidup. Dengannya, manusia juga bisa bijak untukmengembangkan kemampuan atau memperbaiki sesuatu atau memilih pekerjaan yang diinginkan.

Karakter itu lain denga harta kekayaan yang dibedakan dalam antara pengertian anatara keduanya. kekayaan dianggap tidak bisa menjadi ukuran dalam hokum kufu. Perubahan sifatnya sangat cepat, bisa timbul dan tenggelam anatara kaya dan miskin sehingga sulit dibatasi. maka dari itu imam Syafi'i memisahkan harta kekayaan dengan mengutmakan mata pencaharian.

Menurut Abu Bakar, mazahab Syafi’i memisahkan harta kekayaan itu dengan mata pencarian yang dimaknainya, karena dengan pendapat atau pekerjaan itu bisa dijadikan ukuran kufu dalam konsep kufu, karena wanita yang luhur atau yang sholehah dia tidak akan mementingkan harta kekayaan untuk melangsungkan pernikahan, dan itu semuanya dengan seizin walinya apabila bersedia dengan calon yang tidak kaya atau tidak sekufu maka harus minta izin kepada wali wanita, apabila telah setuju maka boleh dilangsungkan pernikahan. ${ }^{81}$

Apalagi perkawinan merupakan ikatan perjanjian dua orang insan untuk bersama selamanya dalam menempuh kehidupan berumah tangga, yang mengharapkan kekal sepanjang hayat. Dan oleh karena itu sebaiknya 
kedua pasangan suami istri harus setaraf dalam banyak hal, supaya rumah tangga yang di harungi lebih mudah dilayari.

Mazhab fikih yang pupuler di Indonesia ini mendasarkan fatwa kufu kepada Al-Quran ketika tidak menjadikan harta sebagai kriteria dalam menetapkan hukum kufu. Pegangannya pada surat Al-Baqarah ayat 221. Dalam ayat itu ada larangan menikahi wanita-wanita musyrik, sehingga mereka beriman, dalam ayat ini juga diterangkan bahwa dilarang menikahkan orang musyrik dengan orang mukmin. Jadi jelaslah bahwa agama lebih diutamakan dari pada harta.

Ayat al-quran adalah An-Nur [24] : 26.

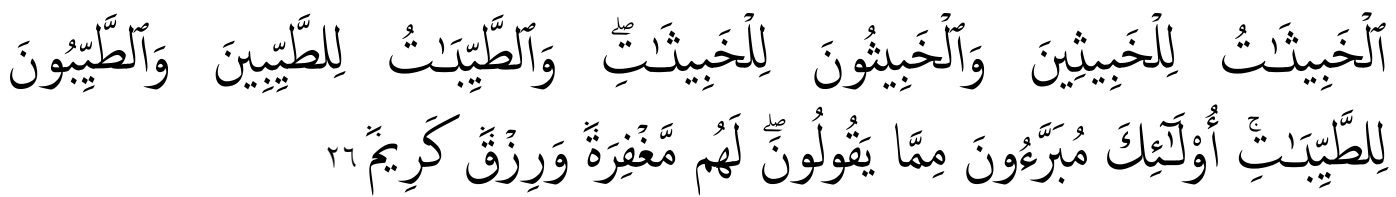

Ayat ini diturunkan untuk menunjukkan kesucian 'Aisyah r.a. dan Shafwan bin Al-Mu'attal r.a. dari segala tuduhan yang ditujukan kepada mereka. Pernah suatu ketika dalam suatu perjalanan kembali dari ekspedisi penaklukan Bani Mushaliq, 'Aisyah terpisah tanpa sengaja dari rombongan karena mencari kalungnya yang hilang dan kemudian diantarkan pulang oleh Shafwan yang juga tertinggal dari rombongan karena ada suatu keperluan.Kemudian 'Aisyah naik keuntanya dan dikawal oleh Shafwan menyusul rombongan Rasullullah SAW. dan para sahabat, akan tetapi rombongan tidak tersusul dan akhirnya mereka sampai di Madinah. Peristiwa ini akhirnya menjadi fitnah dikalangan umat muslim kala itu karena terhasut oleh isu dari golongan Yahudi dan munafik; jika telah terjadi apa-apa antara 'Aisyah dan Shafwan. Masalah menjadi sangat pelik karena sempat terjadi perpecahan diantara kaum muslimin yang pro dan kontra atas isu tersebut. Sikap Nabi juga berubah terhadap 'Aisyah, beliau menyuruh 'Aisyah untuk segera bertaubat. Sementara 'Aisyah tidak mau bertaubat karena tidak pernah melakukan dosa yang dituduhkan kepadanya, ia hanya menangis dan berdoa kepada Allah agar menunjukkan yang sebenarnya terjadi. Kemudian Allah menurunkan ayat yang menunjukkan kepada kaum muslimin bahwa Rasulullah adalah orang yang paling baik maka pastilah 
wanita yang baik pula yang menjadi istri beliau, yaitu 'Aisyah r.a.

Jika kita hubungkan dengan kehidupan kita saat ini, ayat ini menunjukkan bahwa sebenarnya setiap orang pasti ada pasangannya (jodohnya) masing-masing, yaitu yang sesuai dengan tingkatannya (kufu'nya). Sesuai dengan tingkatan yang setara jumlah kebaikannya, jumlah kekurangannya, setara ilmunya (kealimannya), setara dosadosanya baik yang telah dilakukan maupun yang akan dilakukan (Allah Maha Tahu apa yang akan terjadi). Jadi, seorang laki-laki ahli maksiyat sebaiknya tidak perlu memimpikan seorang santri putri yang suci, atau seorang wanita nakal tidak perlu memimpikan seorang ustad yang baik.

Kenyataannya tidak selalu demikian dalam pandangan kita, wallahu a'lam. Allah lebih tahu apa yang sebaiknya terjadi, apa yang baik buat hamba-Nya. Meski kadang-kadang kita tidak bisa menalarnya, karena yang kita ketahui cuma sedikit.

1. Hadis nabi,

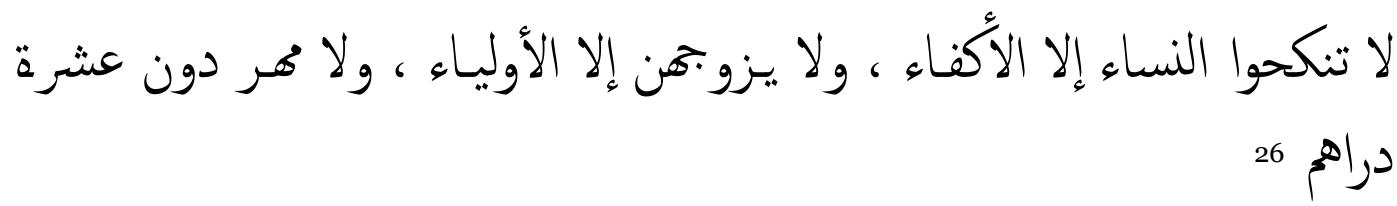

Perempuan bisa dinikahi karena empat hal; Harta, kedudukan, kecantikan dan agamanya, tetapi lebih di titik beratkan kepada agama, harta tidak menjadi pandangan utama dalam konsep kufu. Walaupun harta yang dimaksud dalam hadis diatas adalah bukan banyaknya harta tetapi yang dimaknai dengan harta dalam hadist ini ialah mata pencarian bukan banyaknya harta kekayaan dalam kehidupan, dan mata pencarian yang dimaksud ialah pendapatan atau pekerjaannya disanalah yang menjadi ukuran dalam konsep kufu menurut imam Syafi'i

Konsep kufu ini memberikan hak pilih bagi perempuan untuk menentukan pasangan, apakah setuju atau tidak dengan calon suami. Konsep ini menunjukan bahwa Islam sangat menghormati dan menjunjung kedudukan wanita yang jauh dari kezaliman dan kebatilan.

\section{E. Kufu dalam Kompilasi Hukum Islam}

${ }^{26}$ Ibn Hajar al-Asqalany, Bulūg al-Marām min Adillati al-Ahkām, (Mesir: Dār al- 'Aqīdah, 2003), h. 208. 
Setiap Negara mempunyai hokum perkawinan Islam yang berbedabeda. Karena di Indonesia terdiri dari banyak suku dan landasan hukum yang berbeda. Maka pengadilan agama berinisiatif menyusun sebuah kitab utuk menyeragamkan hukum perkawinan Islam di Indonesia termasuk waris dan sebagian hokum keluarga Islam lainnya. Dengan persetujuan presiden maka tersusunlah kitab yang diberi nama kompilasi hukum islam atau yang biasa disingkat dengan KHI.

Sebagai mazhab yang diakui secara merata di Indonesia, fatwa kufu Syafi'i menjadi pertimbangan penting dalam perumusan KHI. Meski kriteria kufu tidak dibahas secara jelas, namun Bab VI tentang larangan Nikah pasal 40 djelaskan bahwa seorang pria itu dilarang melangsungkan perkawinan dengan wanita yang tidak beragama Islam. ${ }^{27}$

Aturan itu kemudian dipertegas dalam bab X pasal 61 tidak sekufu tidak dapat dijadikan alasan untuk mencegah perkawinan, kecuali tidak sekufu karena perbedaan agama atau (ikhtilaafu al dien). ${ }^{28}$ Jadi telah jelas dalam hukum Islam juga tidak membolehkan mencegah perkawinan hanya gara-gara berbeda kufu. Hokum itu dikecualikan dalam hal agama karena itu bisa mengganggu dalam keharmonisan dalam rumah tangga.

\section{Daftar Pustaka}

'Aini, Abu Muhammad Mahmud ibn Ahmad. al-Bidāyah fi Sharh alHidāyah. Beirut: Dar al Fikr, 1990.

Abdul Aziz Dahlan dkk. Ensiklopedia Hukum Islam. Jakarta: PT. Ikhtiar Baru van Hoeve, 2001.

Al- Jazairi. Al-Fiqh 'Ala Al-Mazāhib Al-Arba'ah, Beirut : Dār al-Fikr, 1969. Asqalany, Ibn Hajar. Bulūgu al-Marām min Adillati al-'Ahkām. Mesir: Dār al- Aqīdah, 2003.

Bakar, Abu. "Kafa'ah Sebagai Pertimbangan Dalam Perkawinan Menurut Mazhab Syafi'i." Jurnal Hukum Kaidah, Voume :18, Nomor : 1, p. 52-65

Ghozaly, Abdul Rahman. Fikih Munahakat. Bogor: Kencana, 2003.

Kompilasi Hukum Islam: Himpunan Peraturan Perundang-undangan. Bandung: Fokus Media, 2012.

Malibari, Zainuddin. Fath al-Mu'īn. t.t.p: Dār al-Ihyā' al-Kutub al'Arabiyyah, tt.

Munawwir, Achmad Warson \& Fairuz, Muhammad. Kamus al-Munawwir Indonesia-Arab. Surabaya: Pustaka Progresif, 2007.

27 Kompilasi Hukum Islam: Himpunan Peraturan Perundang-Undangan (Bandung: Fokus Media, 2012), h. 16 28 Ibid. 
Nur, Djamaan. Fiqih Munakahat. Semarang:Penerbit Dina Utama, 1993.

Nur, Iffatin. "Pembaharuan Konsep Kesepadanan Kualitas (Kafa'ah) Dalam Al-Qur'an Dan Hadis." Kalam: Jurnal Studi Agama dan Pemikiran Islam Volume 6, Nomor 2, Desember 2012, h. 411-436

Nurdin, Subhan. Kado Pernikahan Buat Generasiku. Bandung: Mujahit Pres, 2002

Sayyid Sabiq, Fiqih Sunnah. Bandung: al-Ma'arif, 1981.

Shāfíi, al-Imām Abī Abdillah Muhammad bin Idrīs. al-Umm. Beirut: Dār al-Ihyā' al-Turāṭ al- 'Arabi, 2001.

Soemiati. Hukum Perkawinan Islam dan Undang-Undang Perkawinan; Undang-Undang No.1 Tahun 1974 tentang Perkawinan. Liberty.

Supriyadi, Dedi. Perbandingan Hukum Perkawinan Islam Di Dunia Islam. Bandung: Pustaka Al-Fikri, 2009. 
Hasan Bashori \& Cipto Sembodo 